\title{
Codex Nicholsonianus
}

\section{GEORGE WOUDHUYSEN}

OLIVER NICHOLSON (ED.), THE OXFORD DICTIONARY OF LATE ANTIQUITY. Oxford: Oxford University Press, 2018. Two vols.: A-I, pp. lxxxiv + 1-800, J-Z, pp. xi + 801-1637. ISBN: 9780198662778 . £215.

Frankness is not a quality one naturally associates with Themistius, that most sinuous of the fourth century's official spokesmen, but the opening of his first speech ('On the Love of Mankind') is disarmingly frank. Invited to address Constantius II at Ancyra in the spring of 342, the young orator had an unusually difficult brief: violent riots in Constantinople had recently seen Hermogenes (a senior general) killed by a mob, relations with Constans (emperor in the west) were tense, and war with Persia was rumbling away on the eastern frontier. ${ }^{1}$ The situation surely called for cliché - the familiar refuge of the panegyrist in a tight spot - but Themistius responded with a rather daring candour. Not for him some faltering introduction of the various themes set out in the rhetorical handbooks. Instead, he opened by offering his listeners an expert's guide to the tropes of conventional panegyric: those familiar descriptions of magnificent armies, glittering imperial adornment, and the emperor's physical vigour (Or. $1.2 \mathrm{a}-\mathrm{b})$ to which his courtly audience must have been almost numb. With these curtly dismissed as so much hackwork, he delivered a boldly original oration: a philosophical treatment of the emperor's inner virtue. It is quite a performance. One can see why so many and such different emperors found themselves in need of Themistius' eloquence.

Such a candid exposition of the conventions of a rather mundane genre produces a flicker of awkward recognition in someone reviewing a work of reference, even if their audience is likely to prove more forgiving than Constantius II in a grim mood. Because they generally lack an organising argument or concrete theme, reference works are tricky to review. A few memorable invectives aside, anyone who reads a selection of such reviews cannot help but notice that their authors generally end up awkwardly shuffling around the same few well-thumbed ideas. ${ }^{2}$ These include, but are by no means limited to, the following. The reviewer is in the odd position of having read in full a work which others will only occasionally broach. He or she is conscious of worrying systematically at things (like the

\footnotetext{
I would like to thank Justin Stover for discussion on several important points.

${ }^{1}$ For this date and context, see the thoroughly convincing arguments of Skinner 2015.

${ }^{2}$ For invectives, see e.g. Last 1949 on the first Oxford Classical Dictionary (a volume of which he had initially been an editor!), or Goodyear 1983 on the Oxford Latin Dictionary.
} 
criteria for inclusion) that most readers will experience episodically, if at all. It is far from clear who the average reader of such a work might be, or what they will seek in it. Though there may be much to praise inside the weighty volume(s), there are (no doubt) certain omissions and oversights that ought to be pointed out. Yet that feels slightly mean-spirited in the face of the enormous labour poured into them, labour not always appreciated or recognised. Lurking in the background is the sense of a gap between what such a work ought to do and what it does. It is difficult to shake the feeling that few are likely to read an overview of an overview. As these impulses compete, the review easily becomes an uneasy fusion of fulsome general praise and stilted specific criticism.

Part of the problem is that the standard against which such works ought to be judged is not obvious, or always made explicit. Perhaps best, then, to imitate Themistius and begin candidly. I think that Samuel Johnson can help us with criteria: the man knew a thing or two about reference works, after all. Dr Johnson divided knowledge into two kinds: 'we know a subject ourselves, or we know where we can find information upon it'. ${ }^{3}$ That seems like a good rule of thumb: the dictionary or encyclopaedia ought either to offer the questioning reader the answer that they seek, or tell them where they can find it. That perhaps also helps to unravel the problem of audience a little: reliable information for novices, guidance for those with a little more expertise. Those might seem like modest goals, but there is enormous difficulty in their consistent execution. So, the reviewer should judge the reference work in view of the alternatives that actually exist, not with an eye to what some imagined and perfect project might have achieved. At the same time, to be frank, some of the issues that haunt reviews of reference works seem to me much less important: whether the proportion between different entries is correct, or whether some minor figures have received too much attention, or indeed whether some entries really fall within the scope of the subject. Instead, the review should try to give a sense of the work in the round, of its strengths and its weaknesses, of what a reader ought to keep in mind as they browse.

II.

\section{Assessed against these criteria, The Oxford Dictionary of Late Antiquity (ODLA)} passes with flying colours. At long last, there is a single comprehensive work of reference that covers the whole of the late-ancient world. ODLA cannot, and is not intended to, replace

\footnotetext{
${ }^{3}$ Boswell, Life of Johnson April $18^{\text {th }}$ 1775: 'Sir, the reason is very plain. Knowledge is of two kinds. We know a subject ourselves, or we know where we can find information upon it. When we enquire into any subject, the first thing we have to do is to know what books have treated of it. This leads us to look at catalogues and the backs of books'. Sound advice.
} 
Pauly-Wissowa, The Prosopography of the Later Roman Empire, Encyclopadia Iranica or any of the dozen or so other works of reference that scholars of the period keep to hand (or open in a tab), but it is likely to supplant them as the first port of call for anyone with a basic question. It will make the period enormously more legible to outsiders and to students, likely to rely otherwise on the Catholic Encyclopaedia, the 1911 Encyclopadia Britannica or whatever else (and there are much worse options) lies behind the Wikipedia page in question. Almost twice the length of Late Antiquity: A Guide to the Post-Classical World (1999) and with less need than that bold attempt at synthesis to assert the validity of the category, ODLA reflects both the growth of the subject and its maturation (though it unfortunately lacks its predecessor's rich illustrations). ${ }^{4}$ If you are a scholar of late antiquity and have ever fended off a kindly inquisitor who is under the common but mistaken impression that it is like classical antiquity, but a bit worse, then the very solidity of $O D L A$ is reassuring and perhaps useful. It is fitting that a period which put so much emphasis on the collection and organisation of knowledge has now been codified, even if the 18 years of its gestation did not quite match the speed of Tribonian. ${ }^{5}$ The editor, Oliver Nicholson, his consulting editors (Gillian Clark, the departed Robert Markus and Mark Humphries) and the numerous area advisors and editors can take considerable pride in the end product.

Attractively half-bound in blue leather, the two hefty volumes (A-I and J-Z) are decorated with scenes of cupids at the grape-harvest from a third-century sarcophagus and a Sasanian monarch at the hunt in a fourth-century relief from Taq-e Bostan (respectively). Inside, the interested reader will find unfurled before them the full pageant of late antiquity: over 5,000 entries, organised alphabetically across 1,616 pages - from 'Aachen ambo ivories' to 'Zvart'nots". 6 The entries are printed two columns to the page, in an attractive typeface, at a size and line-spacing relatively easy on the eyes. The ink of one page of my copy (1462, for those interested) had bled ever so slightly, but other than that $O D L A$ is, as an object, a pleasure to read and consult. The entries are preceded by a short (and admirably clear) preface, that sets out the scope and aims of the work, a warm and rather moving set of acknowledgements, capsule biographies of the 400+ contributors, the necessarily lengthy paraphernalia of abbreviations for authors and works, and a shorter note to the reader, setting

\footnotetext{
${ }^{4}$ Bowersock et al. 1999.

${ }^{5}$ The figure is from $O D L A$ ix.

${ }^{6}$ Henceforth, individual entries are referred to by their headwords in quotation marks.
} 
out conventions around names, dates, etc. ${ }^{7}$ At the end of volume II, there are lists of Roman emperors (and usurpers), barbarian monarchs, Persian Kings of Kings and caliphs, as well as bishops of Alexandria, Antioch, Constantinople, Jerusalem and Rome.

The whole work is available online through Oxford Reference, which will (for subscribing libraries) make it easily accessible for students and staff. The Oxford Reference interface, though sometimes a little slow, has a very helpful search function, which makes it possible to trace individuals and themes through the whole work, or answer that half-formed question that lurks stubbornly at the back of the mind. It might be hoped that this online version can be corrected, updated, and extended as time goes on: the digital Oxford Classical Dictionary, with its expansive, even leisurely entries, could serve as a model. The rise of online reference works, with their seemingly limitless possibilities, might make readers of this journal wonder whether a physical compendium like $O D L A$, with its strict word limits, is something of an anachronism. Of course, when the project was conceived, the idea that the future was solely digital was (for most people) just a hazy vision on the horizon. Even so, I am not sure that the volumes of $O D L A$ are a relic of a different era. There are advantages to being able to handle a reference work (fewer broken links, for example) and I find it hard to envisage anyone browsing the headword list on Oxford Reference in the way that one can leaf through a volume. Perhaps that is a failure of imagination, but as long as there exists a 'grand public cultivé' (ix) at whom a work like ODLA can be pitched it is easy to imagine publishers providing them with handsome and imposing volumes: a 'subscription plan renewal notice' does not have quite the same impact when shelved. ${ }^{8}$ At any rate, it seems unwise to count that most late antique technology, the codex, out just yet: it has proved a rather durable format.

Misprints are relatively few and generally trivial. Only a handful of them are more serious. In 'Comitatus', CIL 3.6196 is cited as evidence that the emperor's entourage included both soldiers and civilians. I think it should be 3.6194, the epitaph of the splendidly named Valerius Thiumpus, a soldier. ${ }^{9}$ The head of the imperial secretaries (notarii) was the primicerius notariorum, not the primicerius notarii ('Administration, Roman central civil'). 'Antioch, see of', creates a three-way schism between 'Nicene orthodox and Semi-Arian Bishops and those committed to the doctrines of the council of Nicaea' ${ }^{10} \mathrm{~J}$. Wintjes (not

\footnotetext{
${ }^{7}$ On scope and aims, see the preface (vi): 'to provide easily accessible information, alphabetically arranged, about the history, religion, literature, and physical remains of the half-millennium between the mid- $3^{\text {rd }}$ and mid$8^{\text {th }}$ century A.D. in Europe, North Africa, and Western and Central Asia'.

${ }^{8}$ I wonder also about accessibility: it is easy to envisage libraries with limited budgets preferring a one-off payment for a substantial work of reference to a recurring subscription fee.

${ }^{9}$ His nomen and his role as praefectus of the legio II Herculia strongly suggest a Tetrarchic date.

${ }^{10}$ Surely also we are now beyond such inaccurate terms as 'Semi-Arian'?
} 
Winjes) wrote a biography of 'Libanius', the author of the article cited in 'Fibulae' is D. Janes (not James) and I believe that it is D.R. Sear (not Sears) who produced guides to Roman Coins and Their Values ('Coinage, Roman and post-Roman'). Peter Van Nuffelen (a contributor) frequently appears as Peter van Nuffelen in bibliographies. ${ }^{11}$ 'Images, attitudes towards' has Philo living from 280 B.C. (28?) to A.D. 50, while 'Valentinian III' refers to the emperor's passive attitude to Aëtius' actions in the 330s and 340s (430/40s), and 'Tomis' has Attila capturing the city in 499. In the entry for 'Origen', I think that the first mention of Caesarea in the second paragraph should read Alexandria. There is also a smattering of unsigned entries: I spotted 'Tarragona', 'Bricks and Brickstamps', 'Castel Trosino', 'Els Munts', 'Euphemia', and 'Illyricum'. Nicholson thanks the copy-editors and proof-readers (ix) and they have indeed paid close attention.

In any work of such a scale, there will inevitably also be some inconsistencies of fact. The date of the Constitutio Antoniniana wavers between 211 and 212. ${ }^{12}$ 'Barhadbeshabba 'Arbaya' is said to be 'probably identifiable with Barhadbeshabba of Halwan', but the latter is only 'possibly to be identified with Barhadbeshabba 'Arbaya', which raises all kinds of interesting possibilities (both informative entries are by the same author). The emperor Julian's letters are cited in multiple inconsistent ways. ${ }^{13}$ These are minor points. More concerning is the way that entries vary a great deal in how and how systematically they refer to the ancient evidence: some are peppered with useful parentheses, some are much more selective (and rather less helpful). There are also a fair number of entries (often excellent) that stand in unexplained isolation, as though the obvious complements never made it in: 'Jesus, pagan views of' is an example. ${ }^{14}$

Almost all entries are accompanied by a bibliography, the literature cited generally petering out in the mid-2010s. Some of these are miniature works of scholarship in their own right: 'John Chrysostom', 'Isidore of Seville', 'Inscriptions, Persian', and 'Inscriptions, Roman and post-Roman' struck me as particularly impressive and helpful, but they are far

\footnotetext{
${ }^{11}$ From personal experience, the correct spelling and orthography of Dutch and Flemish names are generally regarded as optional, but one would hope a reference work would get them right.

12 211: 'Naming, systems of, Roman and post-Roman', 'Rome, idea of', 'Aristocracy'. 212: 'law, Germanic and post-Roman'.

${ }^{13}$ Sometimes just by their number in Wright's Loeb ('George of Cappadocia'), sometimes just by the alphanumeric code derived from the 1696 opera omnia of Spanheim ('Didyma'), sometimes by a combination of these ('Libraries'), with the numbering of Bidez and Cumont's authoritative edition thrown in ('Damascus'). ${ }^{14}$ Some others: 'Field systems, Germanic barbarian', 'Homilies, Armenian', 'Initiation, Zoroastrian', 'Place names, British and English', 'Military organization, Germanic'.
} 
from alone. ${ }^{15}$ There are thousands of others with more selective, but still very useful guidance. Those on authors (for example), with their detailed enumeration of editions, translations, and commentaries bring together a vast amount of information otherwise known probably only to specialists: I have found myself using them repeatedly in recent months. There is, however, also a great deal of variation in the length and quality of bibliographies. One could almost believe that different contributors got a very different sense of what was expected of them, some sticking largely to a couple of items (in English) even for lengthy entries on subjects where literature in other languages is vital, while others take a much broader and more expansive view. There have indeed been some rumblings in Germania about the inclination of the bibliographies towards English-language scholarship. ${ }^{16}$ There are few subjects more likely to generate a long and testy discussion amongst Classicists than monoglot Anglophones and their manifold sins, but I have to say that I think this would be misdirected in the case of $O D L A$. There are areas (agricultural topics, for example) where the absence of literature in German, French, Italian, or Spanish is striking, but generally a considerable effort has been made to cite material not in English. The student who consults $O D L A$ is likely to get the impression that while much work has been done in English, English is by no means enough. That strikes me as the right balance.

The preface to $O D L A$ places considerable emphasis on the vastness and diversity of the late antique world and these are not empty assertions. There are a huge number of entries ranging far beyond the Mediterranean to Mesopotamian core, the regions dominated by the 'two eyes of the earth', Rome and Persia, in the third to sixth centuries. In fact, some of the best entries, or strings of entries, are focused on the margins (so to speak), geographically or chronologically: D.W. Phillipson on the Horn of Africa or Edel Bhreathnach on Ireland, for example. Daniel Potts has contributed masses of clear and interesting material on the Persian Gulf and Indian Ocean, while also (with Matthew Canepa and Josef Wiesehöfer) doing much excellent work on Persia itself. Helen Foxhall Forbes offers expert guidance on Anglo-Saxon England, with occasional flashes of dry wit. Nicola Clarke provides incisive biographies of an extraordinary number of Umayyad figures. There is also much on topics that ought to be more central to late antiquity, but which can be difficult to approach. Catherine Hezser, Isaiah Gafni and Alexander Samely (amongst others) open up to the reader the world of late-ancient Judaism: the short guides to rabbinical works in particular will hopefully encourage more

\footnotetext{
15 'Porphyry', in contrast, though full, uses different titles in the bibliography and entry and does not register the Life of Plotinus.

${ }^{16}$ See the helpful review by Brendel 2019.
} 
scholars to dip their toes into this enormously rich material. Christelle Jullien gives a full sense of the extraordinary richness of Syriac Christianity. Efthymios Rizos and Will Bowden do much to make Balkan archaeology accessible to the outsider. Nic Baker-Brian has written almost a miniature handbook in the entries on 'Manichaean Texts' (with excellent bibliographies).

There are areas of consistent strength in more familiar territory too. A large team of contributors with Alexander Skinner, Doug Lee and Christopher Kelly at its heart takes apart the machinery of the late Roman state. Michael Roberts and Gregory Hays offer pithy commentary on dozens of Latin authors and texts. Peter Heather gives measured and sensible guidance on controversial Gothic matters. Simon Corcoran is, as ever, a patient guide through the thickets of legal material. Khaled Anatolios' elegant entries make the Arian controversy seem almost clear. Sophie Lunn-Rockliffe steers the reader through some of the most significant Christian figures of the fourth and fifth centuries with an enviable sureness of touch. Some regions are particularly well-covered: North Africa, by Andy Merrills and Ralf Bockmann, Gaul by Jill Harries and Simon Loseby, Italy by Neil Christie and Spain by Graham Barrett. James Keenan's entries on Egyptian and papyrological subjects are consistently excellent, finely judged to both introduce their subjects and offer critical commentary on them. Distressingly, the 'Contributor biographies' (xxv) ascribe these contributions not to James G. Keenan, professor emeritus at Loyola University, but to James F. Keenan, SJ, Canisius Professor at Boston College, Director of the Jesuit Institute, and prominent Roman-Catholic moral theologian. This is a significant and rather inexplicable error that really ought to have been corrected. Oliver Nicholson's entries (230 sole-authored, contributions to many more), which range over an extraordinary variety of material, are consistently a pleasure, with an eye for the evocative anecdote. Dozens of other contributions and contributors could be invoked as well. The preface expresses the hope (vii) that $O D L A$ will connect specialists in different areas and, from the perspective of an historian, one of the work's best features is the systematic incorporation of entries on archaeological sites, buildings, works of art and archives. It is easy to imagine books and articles emerging from a perusal of these and the realisation that they connect to some familiar text or problem.

Sprinkled through the volume are occasional delightful touches that do much to leaven an otherwise serious and factual diet. To read that 'Dionysius continued to stagger, hog-whimperingly drunk, across the dining-room floors of the great men of Antioch well into the fourth century' ('images of gods') somehow changes one's perspective on the religious strife of the period. It is nice to see the 'monumental self-regard' of 'Volusianus signo 
Lampadius' so deftly punctured. ${ }^{17}$ There is something charming about the idea of Paul the Silentiary as a connoisseur of rare marbles ('Church Architecture'), that Augustine liked dogs enough to allow them into church ('dogs and hounds') or that 'Marius of Avenches' manufactured his own liturgical vessels. The anecdotes that Augustine once preached $e x$ tempore because the lector had chanted the wrong passage of the Bible ('sermons'), that Gregory of Nyssa had to cut short a sermon at Sebasteia because the locals thought he was not showing sufficient respect to their martyrs ('martyr passions, Latin and Greek') and that the first monk to appear in a papyrus (A.D. 324) was involved in breaking up a brawl ('Egypt') offer a variegated sense of the lives of churchmen. One is heartened to be told that 'the Augusti faced no coherent form of performance management' ('Emperor'). It is somehow inspiring too to learn that the Suebians appreciated Honorius, least able of the Theodosian emperors, enough to put him on their coinage long after his death ('coinage, Suebian'). The revelation that Diocletian's vegetable garden, on which he worked so diligently in retirement (Epit. de Caes. 39.6), 'has eluded archaeological investigation' ('Split') is a little disappointing, but surely holds out hope of future discovery. The preface brims over with an enthusiasm for the humorous, the fascinating and the humane in late antiquity and the entries do not disappoint.

III.

All that said, there are areas of the volume that are noticeably weaker, points where readers would be wise to keep their wits about them. Somewhat surprisingly, there is a degree of weakness in the treatment of Roman history of the fourth and fifth centuries. Some of these errors are merely tralaticious, of the kind impossible to avoid in any work of reference. 'Nicomachus Flavianus' (the younger), for example, suggests that he was the recipient of Himerius, Or. 12, 36 and 43. That is the position taken by PLRE I ('Flavianus 14'), by Tim Barnes in a detailed prosopographical study and (more cautiously) by R.J. Penella in his splendid translation. ${ }^{18}$ The texts of the orations are difficult and fragmentary, but the Flavianus whom Himerius addressed seems to have come from Corinth (Or. 12.17) and the other details of his career are very hard to square with what we know of the younger Flavianus. 'Constantius I' is given the praenomen M(arcus), in line with Tim Barnes' indispensable The New Empire of Diocletian and Constantine. ${ }^{19}$ It is true that in a handful of

\footnotetext{
${ }^{17} \mathrm{He}$ is accused by Ammianus 27.3.7 of inscribing his name on grand old buildings to give the impression that they were his constructions.

${ }^{18}$ Barnes 1987: 213-4; Penella 2007: 212-3.

${ }^{19}$ Barnes 1982: 4 and n. 7. PLRE I, 'Constantius 8' omits it.
} 
inscriptions, he does have this name, but in others (very slightly more numerous) his praenomen is given as $\mathrm{C}$ (aius) - most of both varieties are found in North Africa. ${ }^{20}$ Barnes opted for M(arcus) because Constantius was adopted by Maximian, whose praenomen it was, and so ought to have borne it (C(aius) was Diocletian's praenomen). ${ }^{21}$ While the praenomina of Diocletian and Maximian are well attested, Constantius has no such name in the vast majority of the epigraphic evidence, much of it from centres of Tetrarchic activity. It seems most likely that a few over-enthusiastic provincials improved his nomenclature by borrowing from the senior tetrarchs. Constantine similarly crops up very occasionally with the praenomen $\mathrm{M}$ (arcus) or $\mathrm{C}$ (aius), but it is very doubtful that he actually bore either. ${ }^{22}$

These are points where one might hope a work like $O D L A$ would make progress, but cannot expect it. ${ }^{23}$ Other mistakes and omissions are more worrying. 'Constantine, Vision of the Cross of' claims that Eusebius puts this momentous event during the campaign that ended at the Milvian Bridge, but in fact he suggests that the vision happened somewhat earlier (Vita Constantini I.32.1). ${ }^{24}$ For this reason, the vision probably ought not to be assimilated with the dream described by Lactantius (De mort. Pers. 44.5). ${ }^{25}$ The entry for 'Hinton St Mary' omits Susan Pearce's important 2008 article, which argues (quite convincingly) that the famous mosaic with a Chi-Rho portrays not Christ, but Constantine. ${ }^{26}$ When Valentinian I died in 375, Valentinian II was not merely 'put forward' by 'a general' (Merobaudes), but actually proclaimed Augustus ('Gratian'). ${ }^{27}$ 'Valens' was certainly, not probably, born at Cibalae (Libanius, Or. 20.25). The same entry blames his decision to centralise precious metal in the comitatus for the loss of much bullion at the battle of Adrianople, but Ammianus says that the treasure was left within the walls of the nearby city (31.12.10) and suggests that much of it was later extracted (31.16.2). ${ }^{28}$ Hypatia's death occurred in 415 ('Hypatia'), not the fourth century ('disorder, public, Roman and post-Roman').

\footnotetext{
${ }^{20}$ The evidence is summarised by $P I R^{2}$ Flavius 390 . The best example for C(aius) is probably $I L S 649$, that for $\mathrm{M}$ (arcus) probably CIL 8.608.

${ }^{21}$ PLRE I, 'Maximianus 8', 'Diocletianus 2'.

${ }^{22}$ CIL 8.1781, M(arcus); 8.9042, C(aius).

${ }^{23}$ In fact, it sometimes does, see for example Gavin Kelly's entry on 'Nicomachus Flavianus the Elder', which (at last!) corrects his birthdate.

24 'Constantine I the Great' also puts the vision in 312.

${ }^{25}$ This is, incidentally, why 'some scholars conflate' the vision of Eusebius with the epiphany of Apollo described in Pan. Lat. VI.21.3-7, a case very convincingly made by Weiss 2003.

${ }^{26}$ Pearce 2008.

${ }^{27}$ In 'Valentinian II', the reference for his proclamation probably ought to be Ammianus 30.10.5. On these events, see Kelly 2013.

${ }^{28}$ Hendy 1985: 272, $385 \mathrm{n}$. 51 suggested that some ingots found beyond the Roman frontiers might have been seized at Adrianople, but was aware of the problem posed by Ammianus' evidence.
} 
The last western 'consul' was Fl. Paulinus in 534 (as correctly, 'era'), not Vettius Agorius Basilius Mavortius in 527, who was also not the corrector of the Puteanus of Prudentius ('Mavortius'). ${ }^{29}$ The entry on the 'Turcii' is deeply confused. The Apronianus praised by Ammianus (26.3.1-6) was the urban prefect of 362-4, not the prefect of 339 (his father). ${ }^{30}$ Secundus (his brother, not his descendant) was not married to the Proiecta mentioned on the casket from the Esquiline Treasure, but to one Paterna Eunomia (CIL 6.1773). Alan Cameron's article on that famous hoard of silver suggests Secundus' son married Proiecta and also provides a clear overview of the family. ${ }^{31} \mathrm{I}$ am not sure what evidence there is for the 'Symmachi' having their origins in Italy - if Cameron was right about their deep roots (and the case is certainly convincing), then we probably ought to look for their home in the Greek east during the Severan period, which would suit the name. ${ }^{32}$ Symmachus the orator's father was L. Aurelius Avianius Symmachus, not Avienus, ('Symmachi'). ${ }^{33}$ In fact, names are in general handled rather roughly by $O D L A .{ }^{34}$ The decision to list individuals under the name 'most commonly used in English-language scholarship' (lxxxii) is just about defensible, though it is a missed opportunity to teach readers that most late Romans were identified by their last (or diacritical) name. There are, however, also significant omissions and simple mistakes. We are not given the full names of Constantine, any of his sons except 'Crispus', or Julian, though they were rather important. Diocletian's daughter was Galeria Valeria (e.g. ILS 8932), not 'Valeria Galeria'. I can find no evidence that Radagaisus' name was ever spelt 'Radagausius', as he appears throughout ODLA. The famous praetorian prefect, Sextus 'Petronius Probus', also had the nomen Claudius. In addition, he was four times praetorian prefect, with stints in Illyricum, Gaul, and Italy, Africa and Illyricum (twice), not four times prefect of Italy, Africa and Illyricum. He also had five children, not four. ${ }^{35}$ There is an entry for the 'Flaviani', that really ought to have the headword Nicomachi (as passim in book 2 of Symmachus' letters). Readers will find the 'Sevso Treasure' here, even though the metre of the elegiac couplet shows that the owner's name was Seuso. It is disappointing to find references to Avienus ('Petronius Probus, Sextus' and 'Rufii Festi') nearly a quarter century after Cameron very patiently showed that the poet

\footnotetext{
${ }^{29}$ See Cameron 1998.

${ }^{30}$ PLRE I, 'Apronianus 10', 'Apronianus 9'.

${ }^{31}$ Cameron 1985.

${ }^{32}$ Cameron 1999.

${ }^{33}$ PLRE I, 'Symmachus 3', he also had the signum Phosphorius.

${ }^{34}$ There is a good entry on 'naming, systems of, Roman and post-Roman' (by Benet Salway), though it is a pity it is so short.

${ }^{35}$ PLRE I, 'Probus 5'. I suspect the son mentioned by Jerome Ep. 123.17 has been omitted.
} 
Postumius Rufius Festus had the signum Avienius. Anyone hunting for Optatian, the Constantinian composer of remarkable picture poems, will need to look under 'Porfyrius', his signum..$^{36}$

Errors and omissions are by no means confined to matters of prosopography. 'Bible, interpretation and commentary, Latin', does not mention Victorinus of Pettau, author of the first extant Latin commentary on the Bible (well covered in his own entry). It is strange to be told that the Breviarium of 'Festus' had 'little later influence' when it survives so prolifically in manuscripts. ${ }^{37}$ We are also told that 'nothing apart from the name and chronology' links this Festus with the famous and fearsome Festus of Tridentum. Festus the historian wrote his work for Valens in 370, when he was magister memoriae (a title, incidentally, that does not rest on Bamberg E.III.22, one of the most significant manuscripts, alone). Festus of Tridentum was, according to Ammianus 29.2.22, magister memoriae after being consularis Syriae in the mid-360s and before being proconsul of Asia in the 370s. If that is nihil, it is hard to know what would be satis. ${ }^{38}$ The entry on 'Eunapius' omits Barnes' theory that the first edition of the work was issued not long after 378, as well as the very important edition of the Lives of the Sophists by Goulet. ${ }^{39}$ It also makes no mention of the work of François Paschoud, Eunapius' most prolific modern student. ${ }^{40}$ As far as I can tell, no one has ever argued that the Origo gentis Romanae was by Q. Aurelius Symmachus the Younger ('historiography, Greek and Latin') and I am not sure that any evidence exists that could lend even the thinnest of support to that idea. 'Paul the Deacon' did not merely produce a continuation of Eutropius in his Historia Romana, but a massively supplemented and expanded version, because his patron Adelperga had found the Breviarium too short, too dry, and too pagan (as his prefatory letter makes clear). The Mulomedicina of 'Vegetius' has three books, not four: Lommatzsch printed what its preface makes clear is a separate work as its fourth book. The entry on the 'Historia Augusta' devotes considerable attention to the work's putative sources, but fails to mention its use of Aurelius Victor, probably the only significant thing we know about those sources for certain. I also know of no good evidence that 'Orosius' had read the $H A$.

Perhaps because it is the tract of Roman history that I know best, problems seem to cluster especially thick in the second third of the fourth century, the long afternoon of the

\footnotetext{
${ }^{36}$ ODLA has no entry for signa, but see Woudhuysen 2019.

${ }^{37}$ Reeve 1997: 511 says that he has identified 185, and there are doubtless even more to be discovered.

${ }^{38}$ See Kelly 2010.

${ }^{39}$ Barnes 1978: 114-23. Goulet 2014.

${ }^{40}$ See his collected papers Paschoud 2006.
} 
house of Constantine. 'Administration, Roman provincial' gives the impression that there were four regional praetorian prefectures from the time of Constantine and Licinius. This is what Zosimus claimed (2.33.1-2), but contemporary evidence suggests the system of geographical prefectures emerged in a piecemeal fashion over time, reaching its final form only really in the 360s (then only with three, in any case). ${ }^{41}$ Constantine did not introduce the diadem ('regalia, Roman and post-Roman', 'crowns, Roman and post-Roman'); rather his innovation was to wear it at all times (Epit. de Caes. 41.14). ${ }^{42}$ Hannibalianus, Constantine's nephew, was not merely 'king over areas at the northern end of the eastern frontier', but the rather grander rex regum et Ponticarum gentium, as the Origo Constantini 6.35 has it. Incidentally, 'Origo Constantini Imperatoris' is not an 'alternative name' for Anonymus Valesianus I, but its manuscript title and the text is not generally dated c. $390 .{ }^{43}$ Julius Valerius Alexander Polemius, the translator of the Alexander Romance, was a comes of Constantius II if, and only if, he is to be identified with Fl. Polemius, cos. 338 (and I am sceptical) ('Polemius'). ${ }^{44}$ Though the entry hedges, 'Firmicus Maternus' was certainly from Sicily (Mathesis I.praef.4) and the manuscripts of De errore make him a senator. ${ }^{45}$

'Italy' claims that Constans I stayed there only until 340 and that Constantius II remained for only a few months in 354. Neither statement is true and in fact both emperors spent a good deal of time in the region. ${ }^{46}$ The same entry confidently asserts that in 325 Constantine removed the requirement for senators to hold land in Italy. I can find no evidence for a concrete measure of this type and as long ago as the 1960s Fergus Millar suggested that the requirement was already observed largely in the breach in the age of Cassius Dio. ${ }^{47}$ Constantine II died not at 'Aquileia', but in an ambush on the river Alsa nearby (Epit. de Caes. 41.21). 'Constans I' is said to have lived to 351, when he was assassinated in $350 .{ }^{48}$ Throughout $O D L A$, he is credited with the famous rescript to Hispellum, permitting the creation of a temple of the Flavian family there (provided it was not tainted by 'superstition'). That was the position forcefully advanced by Tim Barnes. ${ }^{49}$ It rests primarily on a rather

\footnotetext{
${ }^{41}$ In general, Barnes 1992.

${ }^{42}$ The Epitome de Caesaribus attributes the introduction of the diadem to Aurelian (35.5), cf. Alföldi 1935: 143 $f f$.

${ }^{43}$ See Stover and Woudhuysen 2021.

${ }^{44}$ Lane Fox 1997 ought to be cited as well.

45 On Firmicus Maternus' religion, see now also Woudhuysen 2018.

46 Barnes 1993: 221-5.

${ }^{47}$ Millar 1964: 10.

${ }^{48}$ Libanius Or. 59 is dated in the same entry to 348/9 - Portmann 1989's case for a slightly earlier date ought perhaps to have been signalled.

49 'conventus, provincial', 'Hispellum', 'gladiators', ‘imperial cult', 'Tuscia et Umbria'. Barnes 2011: 20-3.
} 
forced reading of the imperial titulature in the letter and the renaming of Hispellum as Flavia Constans. ${ }^{50}$ As Noel Lenski has pointed out, however, emperors regularly renamed cities after many different members of their families and a date of 333-335 remains the most plausible. ${ }^{51}$ The terminus ad quem of the 'Expositio totius mundi' is 350 (and not any of the various later dates proposed), as Tim Barnes pointed out in passing. ${ }^{52}$

While a proconsul is attested at 'Constantinople' in 342 ( $c f$. 'Proconsul of Constantinople'), it seems more likely that he was the proconsul of the province of Europa, rather than the city. ${ }^{53}$ The entry notes Constantine's institution of a grain-dole in the city, but not Constantius II's cut to it in 342 (Socrates, HE 2.13.5). It seems odd to mention Gallus' residence in 'Antioch on the Orontes', but not that of Constantius II - it had been his de facto capital for much of the 340s and its citizens were attached enough to the emperor to drive Julian to distraction during his stay there (Misopogon 357a-c). The entry on 'Constantius II' gives almost no attention to the theological debates that loomed so large during his reign. ${ }^{54}$ The 'great massacre' at Constantinople in 337 almost certainly took place before the conference in Pannonia that proclaimed Constantine's three sons Augusti. ${ }^{55}$ In 350, there were not 'two surviving male members of the Constantinian dynasty', but four (Constantius II, Gallus, Julian and Nepotian, though one might quibble about him). A considerable period separated Julian's usurpation in Paris in 360 from his armed descent on the Balkans in 361. 'Trier' was not Magnentius' main residence, for he can hardly have spent much of his short reign in Gaul. The devastating earthquake at Nicomedia occurred in 358, not 359 ('earthquakes').

Constantia, the only surviving child of Constantius II and wife of Gratian, does not merit an entry. ${ }^{56}$ She is far from the only important individual active in the fourth century who is omitted. As far as I can tell, not a single praetorian prefect of Constantine or his sons is included in $O D L A$, with the partial exception of C. Annius Tiberianus, because he might be identified with the poet 'Tiberianus'. Some of the prefects are admittedly obscure figures, but

\footnotetext{
${ }^{50}$ Titulature: the inscription lists Constantine as Augustus and Constantine II, Constantius II, and Constans with no title. Barnes (and others) have suggested that this means it can only have been issued in the interregnum between the death of Constantine on the $22^{\text {nd }}$ of May 337 and the proclamation of his three sons as Augusti on the $9^{\text {th }}$ of September. It seems more likely that the stonemason forgot to add nobbb. caesss. (for nobilissimi caesares).

${ }^{51}$ Lenski 2016: 115-17

52 Barnes 1993: 219 and n. 7.

${ }^{53}$ See, briefly, Moser 2018: 132.

${ }^{54}$ See in general Barnes 1993.

${ }^{55}$ See Burgess 2008.

${ }^{56}$ See McEvoy 2016.
} 
others were of enormous significance. It says something that 'Ablabius', a historian of the Goths about whom we next to nothing, makes it in, but not Fl. Ablabius, the Thomas Cromwell of the Constantinian reformation. ${ }^{57}$ Anyone working on a particular period is likely to be more sensitive to omissions in it, but the standards for inclusion seem to vary a good deal over the centuries. The reader of $O D L A$ is more likely to find help on a relatively minor general of the age of Justinian, than some major figure of the middle of the fourth century, like Censorius Datianus. ${ }^{58}$

This is by no means an exhaustive list of errors or omissions and I have not, by any means, checked every reference. The fourth-century Roman Empire is where my interests primarily lie and I am much more likely to spot problems there than in entries on (say) liturgical practices or the history of Central Asia. Many contributions are spotless and I have tried not to underestimate the arduous task of accurately conveying information at such short length. Even so, those with expertise in other periods and other subjects may wish to approach $O D L A$ with a little initial caution.

IV.

Reading a work like $O D L A$ from cover to cover inevitably draws the eye to details, but it also helps to stimulate a more general curiosity. Nagging questions emerge from looking through so many entries, with their crisp summaries of events, persons, and problems. For whatever reason, for me these cluster in the late-sixth- and early-seventhcentury east. I would like very much to know why the quantity of seals - so vital for reconstructing the history of the east Roman state - seems to explode from the sixth century. ${ }^{59} \mathrm{I}$ am similarly struck by the way that the senate of Constantinople - quiescent for most of its history - appears to have played such a significant and such a political role in events of the seventh century. What changed? How did Heraclius supply the large armies that scholars seem to agree he was leading through Transcaucasia in the last great war of antiquity? Any reader of $O D L A$ is likely to find similar spurs to their inquisitiveness. It is the fortuitous way that these spring up, prompted sometimes by topics one has never thought about before, that is surely one of the great joys of reference works.

At the same time, a mighty work of codification like $O D L A$ helps to crystallise a sense of what is being left out, relatively neglected or even ignored, by the subject more

\footnotetext{
${ }^{57}$ PLRE I, 'Ablabius 4'.

${ }^{58}$ PLRE I, 'Datianus I', Censorius is supplied from P. Oxy. 3625.

${ }^{59}$ There is evidence for their use considerably earlier (Still 1993 is a starting point), but this can scarcely be compared to the significance of seals in Byzantine history.
} 
generally. Sometimes this is as simple as the feeling that, for example, Rufinus of Aquileia one of the most idiosyncratic intellectuals of the heroic age of Christian scholarship - cries out for more work. Sometimes it is a more pervasive unease. I mentioned earlier the useful bibliographies for hundreds of late antique authors. These are peppered with the abbreviations $P L$ and $P G$ (often with a helpful note explaining which edition Migne reprinted for the Patrologia). There is an extraordinary amount of detailed philological work to do in a field where a work as raucous, significant and influential as Jerome's Contra Iovinianum still lacks a modern critical edition. It does not feel at the moment as though disciplinary, institutional or broader economic incentives are likely to encourage this kind of scholarship. Yet who knows what treasures may yet be discovered in the manuscripts of even well-known authors? Incidentally, Fortunatian, bishop of Aquileia in the mid fourth century, whose commentary on the Gospels Lukas Dorfbauer discovered in 2012, does not receive an entry. ${ }^{60}$

One impediment to progress on this front is perhaps the way that the field of late antiquity has come to artificially divide the history of post-classical Latin literature (in its broadest sense). ODLA offers rich entries on Arabic, Greek, Armenian, Syriac, and Persian texts and authors written or writing long after its putative terminus in the middle of the eighth century. It takes for granted (rightly!) that these languages have continuous literary traditions from late antiquity into the Middle Ages and that the vagaries of transmission - excerpting, epitomising, rewriting - make it impossible to disentangle late-ancient literature from its still later forms. Yet with Latin, the thread is generally cut in the middle of the eighth century. Paul the Deacon makes it in, but one suspects for his vital role as historian of the Lombards and not for his Historia Romana, the single-most important text for the study of Roman history after Rome, still less for his epochal role in Latin lexicography. Alcuin, to name only one of the imported intellectuals who played such a crucial role in what we (perhaps wrongly) call the Carolingian renaissance, does not. The reader will hunt in vain for Agobard of Lyons, Frechulph of Lisieux, Hincmar of Reims, Hrabanus Maurus, Sedulius Scottus or Theodulf of Orleans, to name only some of the more important figures. ${ }^{61}$ There is no intrinsic reason to treat Latin differently from any of the other literary languages of late antiquity. In fact, $O D L A$ facilitates comparison across languages and genres, comparison that shows how remarkably similar some of the patterns of development are. I am thinking primarily of the

\footnotetext{
${ }^{60}$ Dorfbauer 2013.

${ }^{61}$ The omission of Vergilius Maro grammaticus is also perplexing. Only occasionally in ODLA does the Carolingian period intrude into literary history as in 'Epistolae Austrasicae' (see Barrett and Woudhuysen 2016).
} 
almost universal practice of making epitomes and the crucial role that they play in transmitting late-ancient knowledge to us, but other parallels could be invoked. R.A.B. Mynors, editor of the Panegyrici Latini and Cassiodorus' Divine Institutes, two texts that say so much about the evolution of Latin culture across late antiquity, used to modestly refer to his non-classical interests as 'messing about with manuscripts' ${ }^{62}$ It is hard not to feel, after reading $O D L A$, that a little more of that is needed.

If the division between the late-ancient and the medieval world seems occasionally a little too stark, quite the opposite is true of its beginning. ODLA begins slightly hazily in the middle of the third century: the first emperor registered is 'Decius'. There are entries for a few earlier figures, 'Bardaisan' and 'Numenius', for example, but it is not always clear where the chronological line falls. Tertullian, for example, is omitted, even though it is difficult to understand the sequence of Christian thought and literature in North Africa, from Cyprian to Augustine, without him. So when did late antiquity begin? Surely not with Decius, important as his short reign was (Philip the Arab would have a better claim). In 1971, Brown's original formulation ran (famously) 'from Marcus Aurelius to Muhammad', or 'about AD 200 to about 700'. ${ }^{63}$ I have been teaching on a module on the history of classical scholarship this spring, in which the students have read The World of Late Antiquity. One of the things that they have found eye-opening is the book's daring delineation of the classical world, with a sharply critical eye: its firm sense that a combination of political turmoil, cultural change, and religious upheaval created something new out of something moribund. I am not sure one emerges from reading $O D L A$ with a clear understanding of what changed in the early third century to create late antiquity. If scholars since Brown have extended the chronological and geographical scope of the category, so that it stretches into Abbasid Iraq and reaches deep into Inner Asia (all to the good), it is hard not to feel that the other end of things has been a little neglected.

V.

There is one feature of the arrangement of Mommsen's edition of the Theodosian Code that is both very odd and yet (because his is the standard edition) feels entirely natural. ${ }^{64}$ Before the first book of constitutions, Mommsen printed the remarkable text, found only in a single manuscript (Milan, Biblioteca Ambrosiana C.29), known as the Gesta Senatus, which records the presentation of the Theodosian Code to the Roman Senate in

\footnotetext{
${ }^{62}$ Winterbottom 1993: 380.

${ }^{63}$ Brown 1971: [titlepage] and 7. The famous subtitle seems to have been abandoned in reprints.

${ }^{64}$ Mommsen and Meyer 1905.
} 
438. ${ }^{65}$ Naturally, it also occupies prime position in Clyde Pharr's English translation (perhaps better 'Clyde Pharr's' translation) ${ }^{66}$ Most readers of the Code today, therefore, experience it in a way quite different from anyone in late antiquity or the Middle Ages, perhaps not all that well prepared by their reading of these explosive minutes for the more mundane experience of trawling through imperial pronouncements. The Gesta Senatus is one of the most vivid documents of late antiquity: the full magnificence of late-Roman bureaucratese on display as the Code is introduced and then the serried ranks of senators chanting acclamations for what must have been hours. At first sight, everything seems to have that almost marmoreal smoothness that characterises late antique ceremonial. Anicius Acilius Glabrio Faustus, praetorian prefect and consul, seems totally in control and the reaction of the senators looks blandly ecstatic. It is only on a closer inspection that one begins to see the precise nature of the negotiation that is going on, the way that the senators dilute their general praise with specific criticism and hard-nosed demands. That delicate balance seems the right attitude to ODLA. Like the Theodosian Code, for all that some aspects of it are flawed and some entries are marred by error, it is a magnificent achievement, an extraordinary work of codification, one that will give profit and pleasure to generations of readers. Yet, in closing the second volume, it is hard not to feel that the vast mass of scholarship on late antiquity has yet to find its Justinian.

University of Nottingham george.woudhuysen@nottingham.ac.uk

Bibliography:

PLRE I = A. H. M. Jones, J. R. Martindale and J. Morris (eds), The Prosopography of the Later Roman Empire, vol. I: A.D. 260-395, Cambridge, 1971.

Alföldi, A. 1935: 'Insignien und Tracht der römischen Kaiser', Mitteilungen des Deutschen Archaeologischen Insituts, Römische Abteilung, 50, 1-171.

Barnes, T. D. 1978: The Sources of the Historia Augusta, Brussels.

Barnes, T. D. 1982: The New Empire of Diocletian and Constantine, Harvard, Mass.

Barnes, T. D. 1987: 'Himerius and the fourth century', Classical Philology 82.3, 206-225.

\footnotetext{
${ }^{65}$ Salway 2013 is a brilliant reconsideration of this and other problems.

${ }^{66}$ Pharr 1952. On Pharr's role in the translation, more limited than the titlepage suggests, see Jones Hall 2012.
} 
Barnes, T. D. 1992: 'Praetorian Prefects, 337-361', Zeitschrift für Papyrologie und Epigraphik 94, 249-260.

Barnes, T. D. 1993: Athanasius and Constantius: Theology and Politics in the Constantinian Empire, Cambridge, Mass.

Barnes, T. D. 2011: Constantine: Dynasty, Religion and Power in the Later Roman Empire, Chichester.

Barrett, G., Woudhuysen, G. 2016: 'Assembling the Austrasian Letters at Trier and Lorsch', Early Medieval Europe 24.1, 3-57.

Bowersock, G. W., Brown, P. R. L., and Grabar, O. 1999: Late Antiquity: A Guide to the Postclassical World, Cambridge, Mass.

Brendel, R. 2019: [Review of O. Nicholson (ed) The Oxford Dictionary of Late Antiquity], HSoz-Kult 15.04.2019: https://www.hsozkult.de/publicationreview/id/reb-27975).

Brown, P. R. L. 1971: The World of Late Antiquity: From Marcus Aurelius to Muhammad, London.

Burgess, R. W. 2008: "The summer of blood: the "great massacre" of 337 and the promotion of the sons of Constantine', Dumbarton Oaks Papers 62, 5-51.

Cameron, A. D. E. 1985: 'The date and owners of the Esquiline Treasure', American Journal of Archaeology 89.1, 135-145.

Cameron, A. D. E. 1995: 'Avienus or Avienius?', Zeitschrift für Papyrologie und Epigraphik $108,252-262$.

Cameron, A. D. E. 1998: 'Basilius, Mavortius, Asterius', in I. Ševčenko and I. Hutter (eds), AETOE. Studies in Honour of Cyril Mango Presented to him April 14, 1998, Stuttgart and Leipzig, 28-39.

Cameron, A. D. E 1999: 'The antiquity of the Symmachi', Historia: Zeitschrift für Alte Geschichte 48.4, 477-505.

Dorfbauer, L. J. 2013: 'Der Evangelienkommentar des Bischofs Fortunatian von Aquileia (Mitte 4. Jh.). Ein Neufund auf dem Gebiet der patristischen Literatur', Wiener Studien 126, 177-198.

Goodyear, F. R. D. 1983: [Review of P. G. W. Glare (ed) The Oxford Latin Dictionary (Oxford, 1968-1982)], Proceedings of the African Classical Association 17, 124-136, reprinted in K. M. Coleman, J. Diggle, J. B. Hall, and H. D. Jocelyn (eds) 1992: F. R. D. Goodyear. Papers on Latin Literature, London, 281-287.

Goulet, R. 2014: Eunape de Sardes. Vie de philosophes et de sophistes, 2 vols., Paris. Hendy, M. F. 1985: Studies in the Byzantine Monetary Economy c. 300-1450, Cambridge. 
Jones Hall, L. 2012: 'Clyde Pharr, the women of Vanderbilt, and the Wyoming judge: The story behind the translation of the Theodosian Code in mid-century America', Roman Legal Tradition 9, 1-42.

Kelly, G. 2010: 'The Roman world of Festus' Breviarium', in C. Kelly, R. Flower, and M. S. Williams (eds), Unclassical Traditions. Volume I: Alternatives to the Classical Past in Late Antiquity, Cambridge, 72-91.

Kelly, G. 2013: 'The political crisis of AD 375/376', Chiron: Mitteilungen der Kommission für Alte Geschichte und Epigraphik des Deutschen Archäologischen Instituts 43, 357-409. Lane Fox, R. J. 1997: 'The itinerary of Alexander: Constantius to Julian', The Classical Quarterly 47.1, 239-252.

Last, H. 1949: '[Review of M. Cary, J. D. Denniston, J. Wight Duff, A. D. Nock, W. D. Ross, H. H. Scullard, H. J. Rose, H. P. Harvey, and A. Souter, The Oxford Classical Dictionary, Oxford], The Journal of Roman Studies 39, 193-195.

Lenski, N. 2016: Constantine and the Cities: Imperial Authority and Civic Politics, Berkeley, California.

McEvoy, M. 2016: 'Constantia: The last Constantinian', Antichthon 50, 154-179.

Millar, F. 1964: A Study of Cassius Dio, Oxford.

Moser, M. 2018: Emperor and Senators in the Reign of Constantius II. Maintaining Imperial Rule Between Rome and Constantinople in the Fourth Century AD, Cambridge.

Mommsen, T., and Meyer, P.M. 1905: Theodosiani libri XVI cum constitutionibus

Sirmondianis et leges novella ad Theodosianum pertinentes, 2 vols. in three, Berlin.

Paschoud, F. 2006: Eunape, Olympiodore, Zosime: Scripta minora, Bari.

Pearce, S. 2008: 'The Hinton St Mary mosaic pavement: Christ or Emperor?', Britannia 29, $193-218$.

Penella, R. J. 2007: Man and the Word: The Orations of Himerius, Berkley, California.

Pharr, C. 1952: The Theodosian Code and Novels and the Sirmondian Constitutions. A

Translation with Commentary, Glossary, and Bibliography, New York, New York.

Portmann, W. 1989: 'Die 59. Rede des Libanios und das Datum der Schlacht von Singara', Byzantinische Zeitschrift 82, 1-18.

Reeve, M. D. 1997: [Review of M.-P. Arnaud-Lindet, Festus, Abrégé des haut faits du peuple romain (Paris, 1994)], Gnomon 69.6, 508-513.

Salway, B. 2013: 'The publication and application of the Theodosian Code. NTh 1, the Gesta Senatus, and the constitutionarii', Mélanges de l'École Française de Rome, Antiquité 125.2, 327-354. 
Skinner, A. 2015: 'Violence at Constantinople in A.D. 341-2 and Themistius, Oration I', The Journal of Roman Studies 105, 234-249.

Still, M. C. W. 1993: 'Opening up imperial lead sealings', Journal of Roman Archaeology 6, 403-408.

Stover, J. A., Woudhuysen, G. 2021: 'Jordanes and the date of the Epitome de Caesaribus', Histos 15, XXX-XXX.

Weiss, P. 2003: 'The vision of Constantine' [trans. A.R. Birley], Journal of Roman Archaeology 16, 237-259.

Winterbottom, M. 1993: 'Roger Aubrey Baskerville Mynors', Proceedings of the British Academy 80, 1991 Lectures and Memoirs, 371-401.

Woudhuysen, G. 2018: 'Uncovering Constans' Image', in D. W. P. Burgersdijk and A. J. Ross (eds), Imagining Emperors in the Later Roman Empire, Cultural Interactions in the Mediterranean 1, Leiden, 158-182.

Woudhuysen, G. 2019: 'Myrmeicus or Myrmecius?', Mnemosyne 72.5, 840-860. 